\title{
Pectoral nerves (PECS) and intercostal nerve block for cardiac resynchronization therapy device implantation
}

\author{
Atsushi Fujiwara, Nobuyasu Komasawa* and Toshiaki Minami
}

\begin{abstract}
A 71-year-old man was scheduled to undergo cardiac resynchronization therapy device (CRTD) implantation. He was combined with severe chronic heart failure due to ischemic heart disease. NYHA class was 3 to 4 and electrocardiogram showed non-sustained ventricular. Ejection fraction was about $20 \%$ revealed by transthoracic echocardiogram. He was also on several anticoagulation medications. We planned to implant the device under the greater pectoral muscle. As general anesthesia was considered risky, monitored anesthesia care utilizing peripheral nerve block and slight sedation was scheduled. Pectoral nerves (PECS) block and intercostal block was performed under ultrasonography with ropivacaine. For sedation during the procedure, continuous infusion of dexmedetomidine without a loading dose was performed. The procedure lasted about 3 hours, but the patient showed no pain or restlessness. Combination of PECS block and intercostal block may provide effective analgesia for CRTD implantation.
\end{abstract}

Keywords: Cardiac resynchronization therapy device implantation; Pectoral nerves (PECS) block; Intercostal nerve block

\section{Background}

Effective analgesia and sedation during cardiac resynchronization therapy device (CRTD) implantation is important from the perspectives of surgical procedure and circulation stability (Looi et al. 2013).

The pectoral nerves (PECS) block is relatively easy and reliable peripheral nerve block which was inspired by the transversus abdominis plane block and the brachial plexus block with infraclavicular approach (Blanco 2011). PECS block targets the lateral and median pectoral nerves at an interfascial plane between the pectoralis major and minor muscles (Porzionato et al. 2012). The main indications are breast surgery by tissue expanders or subpectoral prosthesis because the distension of these muscles is rather painful (Blanco 2011) (Blanco et al. 2012).

Here we report the successful application of pectoral nerves (PECS) and intercostal nerve block for CRTD implantation.

\footnotetext{
* Correspondence: ane078@poh.osaka-med.ac.jp

Department of Anesthesiology, Osaka Medical College, Daigaku-machi 2-7, Takatsuki, Osaka 569-8686, Japan
}

\section{Case presentation}

A 71-year-old man (height, $154 \mathrm{~cm}$; weight, $41 \mathrm{~kg}$ ) was scheduled to undergo CRTD implantation. He suffered from chronic heart failure due to ischemic heart disease. NYHA class was 3 to 4 and nonsustained ventricular tachycardia was observed. Transthoracic echocardiography showed an ejection fraction of $20 \%$. He was also on several anticoagulation medications. We planned to implant the device under the greater pectoral muscle. As general anesthesia was considered risky, monitored anesthesia care with peripheral nerve block and slight sedation was scheduled.

Intercostal nerve block at the level of the first and second intercostal space was performed under ultrasonography with $4 \mathrm{ml}$ of $0.375 \%$ ropivacaine. With linear ultrasound probe positioning similar place when performing an infraclavicular brachial plexus block. After identifying the pectoralis major muscle, we checked the location of the pectoral branch of the thoracio-acromial artery between the pectoralis muscles with colour Doppler. Then, we placed $10 \mathrm{ml}$ of $0.375 \%$ ropivacaine into the interfascial plane between pectoralis major and minor muscles (Blanco 2011). The puncture point of the PECS block needle was $2-3 \mathrm{~cm}$ from the surgical point. 
For sedation during the procedure, continuous infusion of $0.4 \mu \mathrm{g} \cdot \mathrm{kg}^{-1} \cdot \mathrm{h}^{-1}$ dexmedetomidine without a loading dose was performed. The procedure lasted about 3 hours, but the patient showed no pain or restlessness. Also, no significant hemodynamic change such as heart rate and blood pressure was admitted (within 10 percent).

\section{Discussion and evaluation}

Analgesia and sedation during CRTD implantation is often challenging, as systemic administration of sedatives and analgesics can disturb circulation (Looi et al. 2013). PECS block is a relatively new peripheral nerve block strategy for breast surgery pain management (Blanco 2011) (Blanco et al. 2012). With PECS and Intercostal nerve block, we can not only provide effective analgesia for relatively long procedures but also avoid the risk of local anesthetic intoxication. Too much local anesthetic administration may lead to the insufficient wound healing, local anesthetic intoxication leading to patient stress (Butterworth 2010). With PECS and intercostal nerve block, we could minimize the dose of local anesthetics under the guide of ultrasonography. However, as there is a risk of peripheral nerve injury by the block needle, we should pay thorough attention during the procedure.

We utilized dexmedetomidine as the sedatives during the procedure. Effect of dexmedetomidine to circulatory and respiratory suppression is relatively smaller compared to propofol (Curtis et al. 2013). Combination of peripheral nerve block and dexmedetomidine sedation may be beneficial for monitored anesthesia care in patients with severe cardiopulmonary problems.

\section{Conclusion}

Our findings suggest that a combination of PECS block and intercostal nerve block can provide effective analgesia for CRTD implantation.

\section{Patient consent}

Written consent was obtained from the patient for the publication of this report.

\section{Competing interests}

The authors have no affiliation with any manufacturer of any device described in the manuscript and declare no financial interest in relation to the material described here.

\section{Authors' contributions}

AF and NK performed anesthesic management of the case, and wrote the manuscript; TM: prepared the manuscript preparation, critical comment and final approval. All authors read and approved the final manuscript.

Source of funding statements

Financial support for the study was provided by our institution and department.

\section{References}

Blanco R (2011) The 'pecs block': a novel technique for providing analgesia after breast surgery. Anaesthesia 66:847-848

Blanco R, Fajardo M, Parras Maldonado T (2012) Ultrasound description of Pecs II (modified Pecs I): a novel approach to breast surgery. Rev Esp Anestesiol Reanim 59:470-475

Butterworth JF 4th (2010) Models and mechanisms of local anesthetic cardiac toxicity: a review. Reg Anesth Pain Med 35:167-176

Curtis JA, Hollinger MK, Jain HB (2013) Propofol-based versus dexmedetomidinebased sedation in cardiac surgery patients. J Cardiothorac Vasc Anesth 27:1289-1294

Looi KL, Lee AS, Cole K, Agarwal S, Heck PM, Begley DA, Grace AA, Virdee M, Fynn SP (2013) Conscious sedation and analgesia use in cardiac device implantation. Int J Cardiol 168:561-563

Porzionato A, Porzionato A, Macchi V, Stecco C, Loukas M, Tubbs RS, De Caro R (2012) Surgical anatomy of the pectoral nerves and the pectoral musculature. Clin Anat 25:559-575

doi:10.1186/2193-1801-3-409

Cite this article as: Fujiwara et al.: Pectoral nerves (PECS) and intercostal nerve block for cardiac resynchronization therapy device implantation. SpringerPlus 2014 3:409.

\section{Submit your manuscript to a SpringerOpen ${ }^{\circ}$ journal and benefit from:}

- Convenient online submission

Rigorous peer review

- Immediate publication on acceptance

- Open access: articles freely available online

- High visibility within the field

- Retaining the copyright to your article

Submit your next manuscript at $>$ springeropen.com 